\title{
Using knowledge exchange between prosumers and enterprises to implement circular economy activities in businesses
}

Roisin Mullins, Institute of Management and Health, University of Wales Trinity Saint David, United Kingdom, r.mullins@uwtsd.ac.uk

Sandra Dettmer, Faculty of Business and Society, University of South Wales, United Kingdom, sandra.dettmer@southwales.ac.uk

Monika Eisenbardt, Faculty of Finance and Insurance, University of Economics in Katowice, Poland, monika.eisenbardt@ue.katowice.pl

Ewa Ziemba, Faculty of Finance and Insurance, University of Economics in Katowice, Poland, ewa.ziemba@ue.katowice.pl

\begin{abstract}
The prosumer engagement conceptual model was considered in light of the Process Classification Framework and how results from Poland and United Kingdom (UK) survey data informed design of the combined prosumer engagement and knowledge exchange conceptual model. The desk literature method was used to review the papers in answering the research propositions. The revised model contains the constructs for supporting prosumer engagement to include sustainability and describes the flow of knowledge sharing and knowledge exchange. Knowledge exchange is the method used to capture and improve enterprise analysis of prosumer knowledge sharing. The sustainability construct includes circular economy philosophy where enterprises evaluate their product and service designs in terms of process stages. The findings confirm the need for increased prosumer engagement as enterprises strive to adopt ways of limiting negative impacts on the environment and improving ethical and responsible business practices. The circular economy is having an impact on all industrial sectors requiring them to evaluate and rethink their processes. The enhancement of the role of prosumers in the circular economy could act as a positive driver for business process changes and aid enterprises in meeting carbon neutral plans. The main contribution of this paper is to offer a novel concept that explains how enterprises can capture and translate prosumer knowledge to inform business strategy within a circular economy setting.
\end{abstract}

Keywords: Consumer knowledge, prosumer, knowledge sharing, circular economy.

\section{Introduction}

The increasing number of research studies published in the area of the Circular Economy (CE) show the growing popularity of the concept in terms of representing an alternative economic model which offers potential solutions to environmental challenges caused by an overuse of limited resources within a linear system, namely the sequence of extraction (of raw materials), manufacture, use and disposal. The heightened interest in this model, which can be defined as "an 
industrial economy that is restorative or regenerative by intention and design" (EMAF, 2013, p. 14), is prevalent not only in organizations but in all their various stakeholder groups. In particular, information technology empowered customers demand organizations to respond to or even lead in efforts to reduce and limit negative environmental consequences resulting from business activities. At the same time, consumers are increasingly taking on the role of prosumers where they actively share their knowledge and experience with the organization with the aim of improving existing processes, activities or end products and services in an innovative and creative way (Lan et al., 2017).

The notion of prosumers and prosumption has been described by numerous authors (Bylok, 2013; Ritzer \& Jurgenson, 2010; Tapscott \& Williams, 2006; Xie et al., 2008). Seran and Izvercian (2014) referred to prosumers in the role of proactive consumers who participate in business process activities. Increasingly, consumers profile themselves on the basis of other customers' reviews of a product or service, and through their own social and financial situations. This profiling referred to as customer stratification is valuable for business analysis and customer follow-up and may be best captured in the knowledge exchange, which is described as the system where the customers' information informs the customer groups as well as the enterprise knowledge base (Vivek et al., 2012). Though CE and Prosumers are typically perceived separately, this study aims to develop a conceptual model which identifies themes that can be used to encapsulate ideas relating to prosumers, knowledge exchange and the CE.

\section{Literature Review on Consumer Knowledge Capture in Enterprise}

When customers communicate with an enterprise, they are conscious of the value of their knowledge sharing especially where they have reported something that would be a new or diverse addition to the current offering and where the resulting change could be feasibly accommodated by the business. In this respect, it is vital for enterprises to distinguish the types of activities that customers deem essential or urgent to share with the enterprise. In this situation, the business value increases because of an external actor's willingness to share knowledge and the enterprise may accordingly take the opportunity to make changes and so keep pace with changing trends and customer styles (Cabrera \& Cabrera, 2002). If the customer is to be recognized for their knowledge sharing, it will be important to reward this behavior in different ways in line with customer expectations. Customers have traditionally used the means available to them to instigate a dialogue or to make contact with an enterprise, but the advent of Web 2.0 created a more open and direct access route to enterprises, greatly accelerating and enriching the levels of communication. The communication may range from initial invitations, to encouraging other customers to join in, in order to reinforce, contradict or supplement particular commentaries. Therefore, there needs to be a variety of tools available and deployed to encourage customers develop a capacity and readiness for knowledge sharing. The enterprise on the other hand is aware of how the open communication can affect other customers or prospective customers (Swan et al., 2000). In this modern communication sharing continuum, the enterprise must determine at what stage they intervene in the communication and for what purpose. The opportunity for enterprises to maximize the returns from customer involvement necessitates a change to the 'old' ways of capturing and responding to customers' feedback. It is desirable to be seen to respond to trends and promote ethical and responsible business practices that are emerging as emerging concerns take precedence over past 
consumer behavior (Al-Alawi, 2005). It is not necessarily the case that all consumers display altruistic behavior, but customer-facing enterprises will be increasingly appraised in relation to their conduct of this dialogue, and their response to the 'new' ways of communication; and how they adapt to this closer involvement of customers with the enterprise, and how this is embraced to drive positive changes in their business.

There is a commercial imperative to profiling customer communication and behavior types as customers increasingly take the lead in initiating the conversation, exploring and exploiting the enterprise offerings and making the data readily available for internal analysis and strategy decisions (Ziemba \& Mullins, 2016). The customer cannot be hushed or ignored without potential for deleterious impacts on the enterprise, either directly or indirectly, and this calls for dedicated systems for future customer involvement practices. The knowledge sharing practices need to be integrated into strategic enterprise practice rather than being detached from it. Chang and Taylor (2016) identified that customer participation may be seen as a complementary strategy in new product development. The specific strategy may depend on the industry type and the business size in terms of how they assimilate knowledge and integrate it into the business. These issues present new challenges for the enterprise in responding to changing customer needs and reconfiguring business practices as appropriate. We conducted studies with consumers to ascertain the degree of their engagement with enterprises as prosumers, and separately how enterprises respond to prosumers in co-creating innovative products and services. Prosumers' knowledge has emerged as a factor in informing business process stages. There are many models and classifications of business processes featured in the literature. Ziemba and Eisenbardt (2015) as well as Ziemba et al. (2018) used the American Productivity and Quality Center (APQC) Process Classification Framework (PCF) to propose a conceptual framework of prosumer engagement in creating business process innovations

\section{Conceptual framework of prosumers' engagement in business processes}

The selection of the APQC PCF is made due to it consisting of "a taxonomy of cross-functional business processes to allow for the objective comparison of organizational performance within and among organizations" (APQC, 2016; Ziemba et al., 2019, p.123). While the APQC framework contains five operating processes, and seven management processes, our amended framework comprises four operational processes in which prosumers' engagement can be specifically exploited for creating offerings, and this framework was applied to prosumers in Poland and the UK. As a result of this analysis, and other research previously reported (Ziemba et al., 2018), it was possible to further modify the framework for each of these four processes. The revised framework provides specific information about the specific types of knowledge prosumers share at the operational level, defined in the four Business Processes (BP) from BP2.0 Develop and Manage Products and Services through to BP5.0 Manage Customer Service. The modified framework used in the research surveys is presented in Table 1.

The conceptual framework of prosumers' engagement describes the business processes by which "prosumers can co-create the concept of a new product (idea generation), co-design new products (development), co-price and co-distribute the new products (commercialization)" (Ziemba et al., 
2019, p. 123). The conceptual framework of prosumers' engagement specifically describes four business processes - development and management of products, namely BP2.0; co-design, marketing and selling of services named BP3.0; co-distribution of new products, BP4.0; and codevelopment of customer services, BP5.0. The framework in Table 1 provides opportunities to explore deep prosumer engagement activities.

Table 1. The Conceptual Framework of Prosumers' Engagement in Business Processes (APQC, 2016; Ziemba \& Eisenbardt, 2015; Ziemba et al., 2018).

\begin{tabular}{|l|l|l|}
\hline Operational Business Processes & Item & Kind of knowledge \\
\hline \multirow{5}{*}{$\begin{array}{l}\text { BP2.0 Develop and Manage } \\
\text { Products }\end{array}$} & P1 & New product design \\
\cline { 2 - 3 } & P2 & Materials from which the product was made \\
\hline & P3 & Package or graphic elements of the product \\
\hline & P4 & Product functionality \\
\hline & P5 & Reliability and durability of the product \\
\hline & P6 & Ease and intuitiveness of product use \\
\cline { 2 - 3 } & P7 & Product performance \\
\hline BP3.0 Market and Sell Services & S1 & Advertising / marketing \\
\cline { 2 - 3 } & S2 & Pricing strategy \\
\cline { 2 - 3 } & S3 & Promotions, discounts, loans \\
\hline BP4.0 Deliver Services & S4 & Service availability and distribution channels \\
\hline & S5 & Ordering process \\
\hline BP5.0 Manage Customer Service & S6 & Complaint handling and warranty services \\
\cline { 2 - 3 } & S7 & Customer service \\
\hline
\end{tabular}

The previous research used the APQC conceptual framework (Ziemba \& Eisenbardt, 2015; Ziemba et al., 2018) to identify the nature of business processes, the way that knowledge may be shared, the variety of incentives that engage prosumers and the range of Information and Communication Technologies (ICT) tools used to establish a connection with customers. The results from the previous research informs the design of the new conceptual models for prosumer engagement and knowledge exchange reported in this paper.

\section{Research Propositions}

The focus of a large number of papers and research on the $\mathrm{CE}$ is in the identification of supportive business models, conceptual frameworks, barriers and opportunities for CE implementation or industry-specific case studies. Only a few papers highlight the importance of consumers' activities and their impact on the CE (Lieder \& Rashid, 2016). Furthermore, only a few studies acknowledge the lack of information and knowledge as a barrier towards the adoption of $\mathrm{CE}$ business models (Tura et al., 2019). Following on from the confirmation of prosumers as active participants in terms of value identification and creation within business processes (Ziemba et al., 2018), we can see potential benefits by bridging the gap between the concepts of prosumers and CE: Organizations benefit from the external knowledge provided by prosumers to identify $\mathrm{CE}$ opportunities and businesses can respond to prosumers demanding ecological credentials. 
To investigate the research gap, the following research propositions were formulated:

\section{Research Proposition 1:}

Define a new conceptual model which combines the concepts of prosumers and CE.

\section{Research Proposition 2:}

The current literature identifies linkages between the concepts of prosumers and the $\mathrm{CE}$ through the specific themes of Business Processes, Incentives, ICT and Sustainability which can be summarized in a conceptual model.

\section{Research Methodology}

To work towards testing the first research proposition, we applied the previous research on prosumers carried out by Ziemba and Eisenbardt $(2015 ; 2016)$ as well as Ziemba et al. (2018) in the formulation of a conceptual model. In a second step, this model was expanded to consider the increased focus of consumers on sustainability credentials within organizations, as illuminated in the academic literature. Subsequently, we addressed the second proposition by conducting a search of the $\mathrm{CE}$ literature where we examined a number of articles for the themes identified in the developed conceptual model, which are Business Processes, Incentives, ICT and Sustainability. In order to identify relevant articles in the area of the CE, we searched the term "Circular Economy" in the research databases Ebsco and Elsevier which yielded 18 relevant papers (see Table 2).

\section{Results and Findings}

\section{The Combination of the Concepts of Prosumers and Circular Economy}

This study analyzed to what extent prosumer engagement is determined by the choice of business activity, customer motivation and the communication tools. Following the brief literature review, we are proposing a novel conceptual model, which can be visualized in Figure 1. The prosumer engagement can be regarded as one-way communication. However, to demonstrate real impact in the enterprise, the knowledge management systems in place needs to ensure it is a two-way communication process which allows enterprises to respond to customers' proposals, suggestions

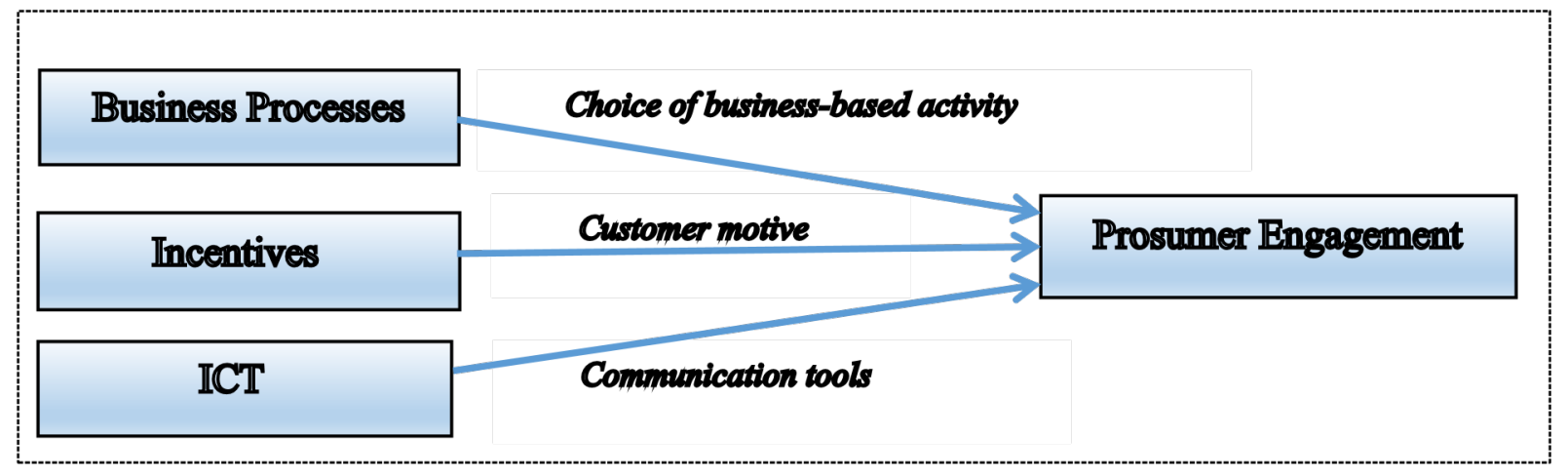

Figure 1. Novel Conceptual Model of Prosumer Engagement with Enterprise 
and schemes through changes in their strategy, product or service offerings or specific activities. Therefore, the requirement for a knowledge exchange system is vital to capture the prosumer engagement and release the converted knowledge into internal value, removing barriers to utilization of prosumer engagement encountered with outmoded Customer Relationship Management (CRM) tactics, and thereby enabling the desired two-way communication.

The knowledge exchange is vital to encourage engagement with companies and develop a social customer relationship using social media channels (Baird \& Parasnis, 2011), and importantly move away from traditional CRM approaches. Further, Lacy and Rutqvist (2015) explained the importance of 'social technologies' which are essentially the technologies implemented to create the community around the consumers and integrate them into the value chain to improve enterprise communication practices. An important enterprise practice is to develop trust between all parties and this will affect the outcome. Jordens (2015) suggested that "transparency and information sharing develops trust (Kwon \& Suh, 2005), because it reveals that partners have nothing to hide and information asymmetry is reduced. Conversely, transparency and information sharing also grows parallel to the levels of trust (Ghosh \& Fedorowicz, 2008)" (Jordens, 2015, p. 16). The negative consequences of information asymmetry may be removed through an effective information sharing and knowledge exchange process.

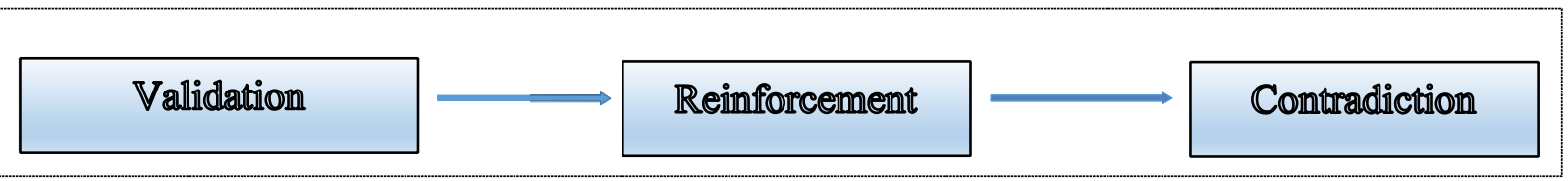

Figure 2. Customer Stratification Model to Analyze Knowledge Exchanges

(Ziemba \& Mullins, 2016)

The challenge for organizations is in determining how to distribute the knowledge internally and release it in a revised communication offering that is more acceptable and useable. As Nonaka and Takeuchi (1995) demonstrated in their Socialization-Externalization-Combination-Internalization (SECI) model, there are different ways to transform knowledge (Nonaka, 1994) from tacit into explicit knowledge and vice versa. The knowledge change in the SECI model is summarized as tacit to tacit (Socialization), tacit to explicit (Externalization), explicit to explicit (Combination), explicit to tacit (Internalization) (Nonaka, 1994; Lee \& Kelkar, 2013). The knowledge type identified as internalization is important in stating how customer knowledge is used and learned, i.e. shared and created in the enterprise.

The research findings from Ziemba and Mullins (2016) suggested three stages of an internalization knowledge creation process and can be referred to as a customer stratification model. The resulting conceptual model of customer stratification explores how enterprises should use customer's reviews and discussions to gain insightful knowledge about and from customers and is illustrated in Figure 2. This is regarded as the end phase as it is an internal analysis exercise, but the outputs should be embedded into the CRM systems through feedback modules. "The customer search and profiling can be referred to as customer stratification, and the approach to this needs to be addressed if businesses value customer knowledge exchanges" (Ziemba \& Mullins, 2016, p. 174). This stratification approach can provide valuable insights and guidance for researchers and practitioners as well as enterprises in outlining the profiling challenge as well as to rationalize 
behavioural effects that resonate in Web 2.0 communities outside the established boundaries of the enterprise.

\section{Summary of Findings from Using the Conceptual Model of Prosumers' Engagement}

The conceptual framework of prosumers' engagement in business processes (Table 1) was used to address each process stage and the results confirmed the adoption of the conceptual model for determining the antecedents for prosumer engagement.

\section{Business Processes}

Results for BP2.0 Develop and Manage Products, confirmed that Poland prosumers are more disposed towards sharing all kinds of knowledge about products in the future. Specific kinds of knowledge relating to the product cycle that warrant attention are P4, P5, P6, and P7 (see Table 1 for definitions) in order to encourage prosumers' knowledge sharing in the future (Ziemba et al., 2018). This indicates that there is a need for a more refined and focused use of customer engagement and feedback strategies to ensure better customer engagement in this nuanced part of the product cycle (Huang et al., 2016). For example, product performance is regarded in the UK as one of the primary drivers for business success in competitive markets. While other studies examine prosumer engagement for products and services that are already on the market (Piller, 2008), our studies investigate prosumers' willingness to provide feedback on preferences for products and services that are still in the early stages of the product life cycle (Ziemba et al., 2018; Mullins et al., 2019). This is an important difference, as where business is able to assess prosumers primary concerns and subsequently act on this information by changing designs earlier in the process, especially where this feedback pertains to sustainability concerns, it may be understandable that higher priority will ultimately be placed upon these fundamental important design factors that are becoming increasingly influential in determining why a product is bought. Similarly, packaging issues may be of higher priority as sustainability concerns increase (Orzan et al., 2018).

Engaging prosumers in knowledge sharing relevant to process BP3.0 market and sell services including (S2) pricing strategy were indicated to be of higher priority to Poland prosumers in the future but were not rated at all highly by the UK-based prosumers, and the prosumers of both countries were equally ambivalent about sharing knowledge regarding promotions (S3) (Mullins et al., 2019). However, this to some extent may be related to the older age of the respondents in our studies, as younger generations use social media much more in their knowledge sharing, this may well change in the future in keeping with consumption practices more widely (Belk, 2014). Interestingly, there was less difference between Poland-based and UK-based prosumers in knowledge sharing associated with customer-facing processes, namely BP4.0, the service order process and process BP5.0, managing the customer services. There is concurrence in the extent to which Poland-based and UK-based prosumers are willing to share service process knowledge with enterprises, prosumers in both countries being equally keen to share knowledge on the ordering process (S5). Actively considering ownership of the process will be more common in the future and authors such as Botsman and Rogers (2010) have suggested that rethinking ownership through the prism of collaborative consumption will be a major part of modern practice in enterprises, 
possibly even forming a new business paradigm. Managing customer services may also be increasingly affected by wider ethical concerns, such as where outsourcing service processes, including call centers, to parts of the world where there remain endemically low wages and poor workers' rights, will be more widely and more directly scrutinized.

\section{Incentives}

Groh et al. (2010) studied the role of collaboration in sharing of knowledge in communities and found that participation may be strengthened by offering incentives to specifically encourage community engagement and knowledge sharing. Measuring the outlook for knowledge sharing incentives from prosumers in the future revealed interesting country-specific preferences (Hafkesbrink \& Evers, 2010) and confirmed it as a significant construct, deserving incorporation in our model considering prosumer engagement.

Researchers such as Chouikha (2016), Janzik and Herstatt (2008), as well as Vuori and Okkonen (2012) have separated incentives that encourage "knowledge sharing into two types: tangible and intangible. Tangible incentives mainly involve monetary compensation, bonus points with financial value, and premiums in the form of free products" (Ziemba \& Eisenbardt, 2016, p. 148), whereas the intangible incentives involve enhancement of the expertise, status, reputation, and recognition of individuals. An earlier study by Greenberg and Liebman (1990) reported that:

Incentives fall into three categories: material, social and activity. Material incentives are linked to (tangible) revenue and financial benefit. Social incentives operate on the interpersonal level by allowing people to openly identify themselves with the company, co-workers, customers or even competitors. (more like the intangible recognition factors) (Ziemba \& Eisenbardt, 2016, p. 148)

Activity incentives provide opportunities to fulfil a challenging enterprise action or task and in turn fulfil a personal sense of accomplishment. Yet more recently, Ho and Kuo (2013) confirmed that these kinds of incentives have yielded significant influences on the knowledge sharing behavior of community participants. The incentives operating in this construct are categorized into five types (Ziemba \& Eisenbardt 2017, p. 79):

- Tangible incentives;

- Intangible incentives - activity incentives;

- Intangible incentives - social incentives;

- Intangible incentives - tool-related incentives; and

- Intangible incentives - promotion-related incentives.

The tangible incentives include samples of products, bonus points and rewards that have a financial value (Chouikha, 2016; Janzik \& Herstatt, 2008; Vuori \& Okkonen, 2012), and were unsurprisingly more interesting to prosumers than the intangible incentives of less direct immediate benefit. Consequently, the intangible incentives such as activity incentives are viewed by prosumers as less important than tangible ones. Prosumers were found to regard social incentives as less important but this was also found to be linked with lower educational backgrounds suggesting that intangible incentives were more favorably received by those who value "cooperation with people who share passions, skills, knowledge and experience, build peer recognition, status, reputation, and strengthened social ties with enterprises and customers" 
(Ziemba \& Eisenbardt, 2016, p. 161). As prosumers become more educated and well versed in online collaboration and sharing, it is likely that social incentives will come to be regarded as more important. Finally, promotion-related and tool-related incentives were found to have the least influence on prosumers' knowledge sharing. Promotion-related incentives include collaboration on "co-creating promotional materials, engaging with promotional or advertising campaigns in various media" (Ziemba \& Eisenbardt, 2016, p. 161), as well as identifying with promotional information found accidentally, while the "tool-related incentives include utilization of contemporary and innovative ICTs, invitations by e-mail, invitations through social media such as Facebook, interesting blog, attractive video on YouTube, and even online games" (Ziemba \& Eisenbardt, 2016, p. 161). These incentives are ICT-intensive and the style of communication and methods of delivery may be more disposed towards their already wide use in social and entertainment settings, than towards being such a good fit to the needs of prosumers in a business setting.

\section{ICT}

Interestingly the choice of specific ICT for prosumer engagement indicated where the enterprise can prioritize engagement, as the most substantial difference found in the expected use of ICTs by prosumers relates to mobile applications with Poland use at 33\%, whereas UK use was $88.2 \%$ (Ziemba et al., 2016). These findings indicate that mobile applications are very much the 'expected ICT' means by which 'UK-based prosumers share knowledge, followed by use of Facebook and the company websites, whereas Polish prosumers expect to engage first and foremost with use of the company websites, followed by e-mails and industry sector-specific portals" (Ziemba et al., 2016, p. 10). Interestingly, crowdsourcing portals and blogs are ICTs that neither UK based nor Polish prosumers expect to use or demonstrate any preference to use. It is evident that enterprises need to embed a comprehensive selection of ICT's to cater to all their prosumers' needs in order to actively encourage knowledge sharing. Emerging global challenges and new ICT trends will no doubt influence patterns of knowledge sharing in the coming decades, (Ziemba et al., 2016).

\section{Circular Economy and Changing Global Economies}

Natural disasters, climate change, deforestation, loss of biodiversity and resource depletion are just some of the pressures which have sparked national and international movements for sustainability (Geisdoerfer et al., 2016; Korhonen et al., 2018). The increased awareness of sustainability in economies, business and society has reached customers and therefore prosumers too. The desire to protect the environment is particularly strong in younger generations and given their typically higher ICT literacy, this offers opportunities for enterprises to gauge the increased demand for environmentally friendly products and services. As the internet has led to a new level of transparency in terms of internal business processes, consumers now have the opportunity not just to assess and evaluate a given company based on the purchased product or service but also in terms of sustainable operations and behavior. More specifically, interested customers have access to information regarding specific business processes such as those outlined in the framework specified in Table 1 (Ziemba et al., 2018). Furthermore, the shift in consumer awareness towards sustainability results in a genuine desire by consumers to positively contribute to the conservation of the planet through the sharing of knowledge and ideas to help businesses respond to the 
environmental needs. By this reasoning, the conceptual model as detailed in Figure 1 has been updated and includes sustainability on the left-hand side of the model as another antecedent that drives prosumer engagement. As outlined earlier, the engaged, informed and active customer with an aspiration to do something good for the business, environment and society, is not satisfied with a one-way communication, but wants to observe the organizational response in terms of changes in strategy, current product and service offerings and organizational behavior (Geisdoerfer et al., 2016.

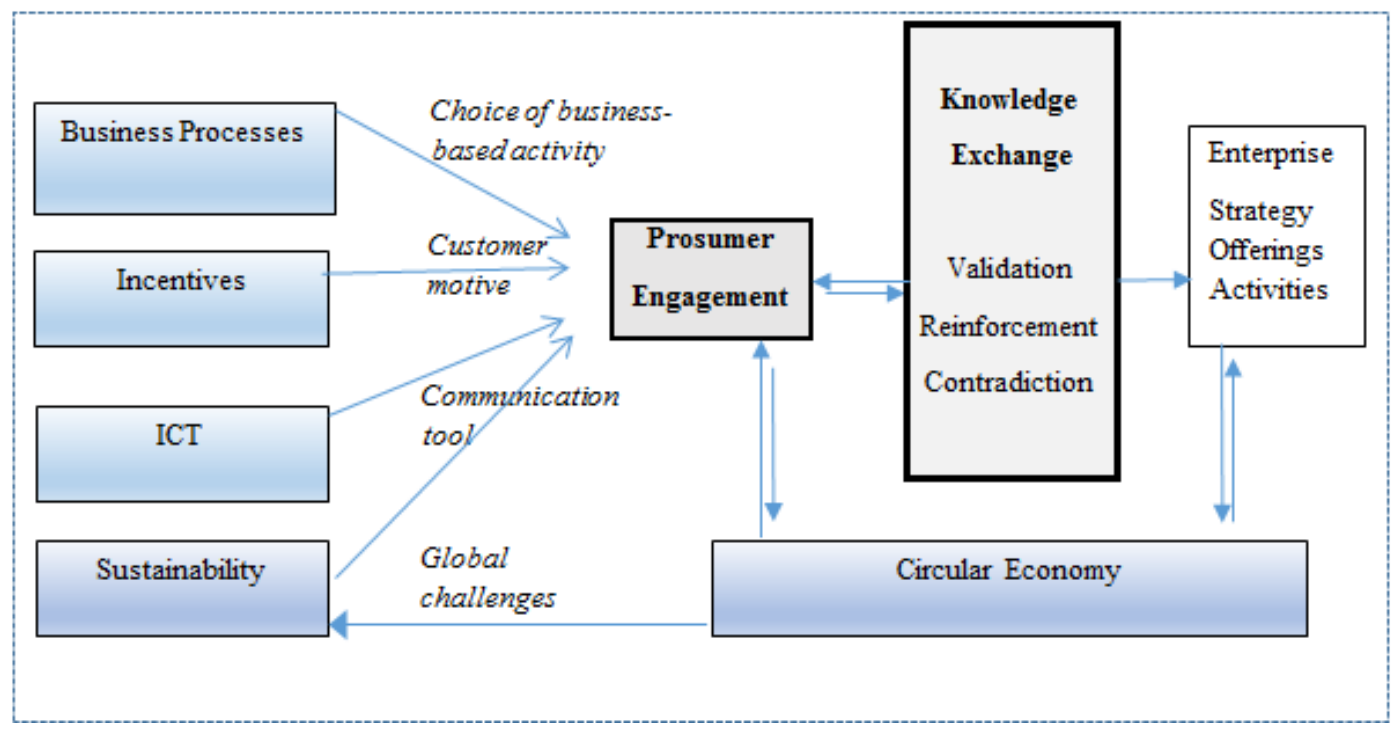

Figure 3. Conceptual Model of Prosumer Engagement and Knowledge Exchange

The conceptual model in Figure 3 illustrates that it is possible to combine the concepts of prosumers and CE in a conceptual model (Research Proposition 1). As an example, Lan et al. (2017) explored value co-creation in relation to the sharing economy and suggested that "value co-creation between prosumers and firms is not only a form of social innovation in itself, but also a key channel to realize the potential of the sharing economy in transforming cities towards sustainability" (p. 3). The knowledge exchange has the potential to enable value co-creation between prosumers and enterprises and realize their economic, environmental and global concerns.

The online representation of enterprises (organizations) means that customers can contact the business and leave feedback, ask questions and give general comments. As previous research has shown (Ziemba et al., 2018), customers are generally willing to share knowledge with enterprises and would like to do so even more in the future. Enterprises absorb this information and benefit from the external knowledge pool which they can access for no or very little cost. Lan et al. (2017) explained the need for "possible value co-creation spaces with firms to carry out design, manufacturing, distribution, and other critical processes" (p. 2). However, it remains unclear how the enterprises use the knowledge and to what extent it will be translated into actions. By implementing the customer stratification model from Figure 2, the impact of knowledge exchange on business strategy is realized through the stages of validation, contradiction and reinforcement. The knowledge exchange is a type of co-creation space, a customer profiling module and the vital dual communication connection between prosumers alongside the enterprises. Furthermore, the 
updated conceptual model highlights the need for more targeted customer input as prosumers demand evidence of the knowledge exchange within the organization. This applies especially to customer inputs which suggest changes in order to make enterprises more sustainable. Organizations may regard such actions only as additional cost factors (Rizos et al., 2015) and customers may fear businesses use greenwashing as part of their sustainability and Corporate Social Responsibility (CSR) strategy (Ramus \& Montiel, 2005).

\section{The Linkages Between the Concepts of the Prosumer and the Circular Economy}

The second Research Proposition suggests that the concepts of prosumers and the CE can be joined through four specified themes in the conceptual model presented in Figure 3. In order to address this statement, $18 \mathrm{CE}$ research articles have been reviewed as to whether they consider Business Processes, Incentives, ICT and Sustainability to have an impact on the CE. More specifically, the four proposed themes are considered to be relevant for the CE implementation in businesses at different levels and in different functions. The Business Processes focus on the operational approach, Incentives present tactical measures, ICT accounts for the technical perspective and Sustainability is linked to the longer term strategic fit as it will form part of the CSR framework of organizations. The results of this analysis are presented in Table 2.

Table 2. Themes Within the CE Literature Linked to Prosumer Conceptual Model

\begin{tabular}{|l|l|l|l|l|}
\hline Literature Source & $\begin{array}{l}\text { Business } \\
\text { Processes }\end{array}$ & Incentives & ICT & Sustainability \\
\hline Tura et al. (2019) & $\mathrm{x}$ & $\mathrm{x}$ & $\mathrm{x}$ & $\mathrm{x}$ \\
\hline Moric et al. (2020) & $\mathrm{x}$ & $\mathrm{x}$ & & \\
\hline Pagoropoulos et al. (2017) & & & $\mathrm{x}$ & \\
\hline Upadhyay et al. (2016) & $\mathrm{x}$ & $\mathrm{x}$ & $\mathrm{x}$ & $\mathrm{x}$ \\
\hline Stahel (2016) & $\mathrm{x}$ & $\mathrm{x}$ & & \\
\hline Geissdoerfer et al. (2016) & $\mathrm{x}$ & & & $\mathrm{x}$ \\
\hline Romero et al. (2017) & $\mathrm{x}$ & & & $\mathrm{x}$ \\
\hline Barr et al. (2011) & & $\mathrm{x}$ & $\mathrm{x}$ \\
\hline Ritzen et al. (2017) & $\mathrm{x}$ & & & \\
\hline Reim et al. (2017) & $\mathrm{x}$ & $\mathrm{x}$ & $\mathrm{x}$ \\
\hline Michelini et al. (2017) & & $\mathrm{x}$ & $\mathrm{x}$ & $\mathrm{x}$ \\
\hline Lieder et al. (2016) & $\mathrm{x}$ & & $\mathrm{x}$ & $\mathrm{x}$ \\
\hline Lauman et al. (2018) & $\mathrm{x}$ & & $\mathrm{x}$ & $\mathrm{x}$ \\
\hline Kalmykova et al. (2019) & $\mathrm{x}$ & & $\mathrm{x}$ & $\mathrm{x}$ \\
\hline Jabbour et al. (2019) & $\mathrm{x}$ & & $\mathrm{x}$ \\
\hline Gnoni et al., (2017) & $\mathrm{x}$ & & $\mathrm{x}$ \\
\hline Galvao et al., (2018) & & $\mathrm{x}$ & $\mathrm{x}$ \\
\hline Korhonen et al., (2018) & & & $\mathrm{x}$ \\
\hline
\end{tabular}


As the results show, 15 of 18 papers published on the CE topic, address the issue of business processes and more specifically mention the need for circular business processes, increased transparency in the supply chain, heightened technical difficulties in handling CE material flow etc. As expected for publications on the CE, sustainability is a specific focus, with 14 of the 18 papers addressing sustainability of organizations as part of their CSR efforts. Incentives in form of social drivers, value creation, resource independencies and decreased price volatilities are discussed in seven papers. Surprisingly, ICT has mainly been identified as a barrier towards CE implementation and is mentioned in seven of the 18 papers.

The CE Framework, as outlined by the Ellen McArthur Foundation (2012; 2013), offers practical approaches to overcome these concerns and provides intersection points between customer knowledge input and the conceptual framework specified in Table 1. The limitations of the shrinking ecosystem places specific challenges on enterprises. With a rising and increasingly affluent population comes an undampened global demand for consumer and producer goods which inevitably leads to an increasing scarcity and price volatility of many raw materials and hence the supply of those raw materials is no longer guaranteed (World Economic Forum, 2014). Customers on the other hand ask for increasingly higher green credentials for products and services and given the online transparency of organizations and opportunities for increased scrutiny, customers are becoming more empowered and demand a concerted implementation of sustainability efforts (Barr et al., 2011). Furthermore, businesses now face additional costs not only for the disposal of manufacturing waste, but producers and retailers also need to bear the cost of end of life disposal following the Extended Producer Responsibility (EPR). Therefore, it has now widely been accepted that businesses and societies need to change their current approach of linear thinking to overcome the outlined issues and a different 'economic systems thinking approach' is necessary as an alternative to the classical linear consumption patterns of take-make-use-dispose. A new approach in form of the circular economy (EMAF 2012; 2013) offers opportunities and solutions to the overuse of resources. The circular economy aims to separate economic growth from the consumption of finite resources by maintaining the product value at the highest possible level in a closed loop system for as long as possible. The different stages are described as maintaining, prolonging and sharing by the users themselves, re-use and redistribution through the service provider, refurbish and/or remanufacture with the help of the product manufacturer and as a final resort, recycling in collaboration with the parts manufacturer. Thus, the CE approach requires active participation of the consumers which is in line with prosumption theory (Zimba \& Eisenbardt, 2015). Parallel developments can be observed in the new consumption culture where user groups and communities rethink and change their behavior in favor of sharing the use of the function, service and value of the physical products (Tukker, 2015) and which is collectively regarded as the sharing economy. Individuals are urged to engage in a range of pro-environmental practices that address both specific and local environmental problems as well as major global challenges such as climate change. Individual consumers are willing to substitute ownership with general user rights as a way to combat resource intensive consumerism in order to achieve positive environmental effects at a local as well as a global level. Consumers are acting as agents of change within the capitalist economy and the notion of 'citizen-consumers' is created (Barr et al., 2011). The question of how consumers and prosumers interact with organizations has been captured in the analysis of the impact of ICT on prosumer activity (Ziemba \& Eisenbardt, 2016). Similarly, digital technology can help with "the transition to a circular economy by radically increasing 
virtualization, dematerialization, transparency, and feedback driven intelligence" (EMAF, 2019, p. 19). Finally, Table 3 provides examples of how proposed CE activities correspond to the initial conceptual framework and expands on sustainability issues and activities that feed into the conceptual framework (Figure 3). By doing so, this preliminary study concentrates on the operational level in order to identify specific opportunities for CE implementation in enterprises.

Table 3. The Framework of Prosumers' Potential Areas for Circular Economy Activity

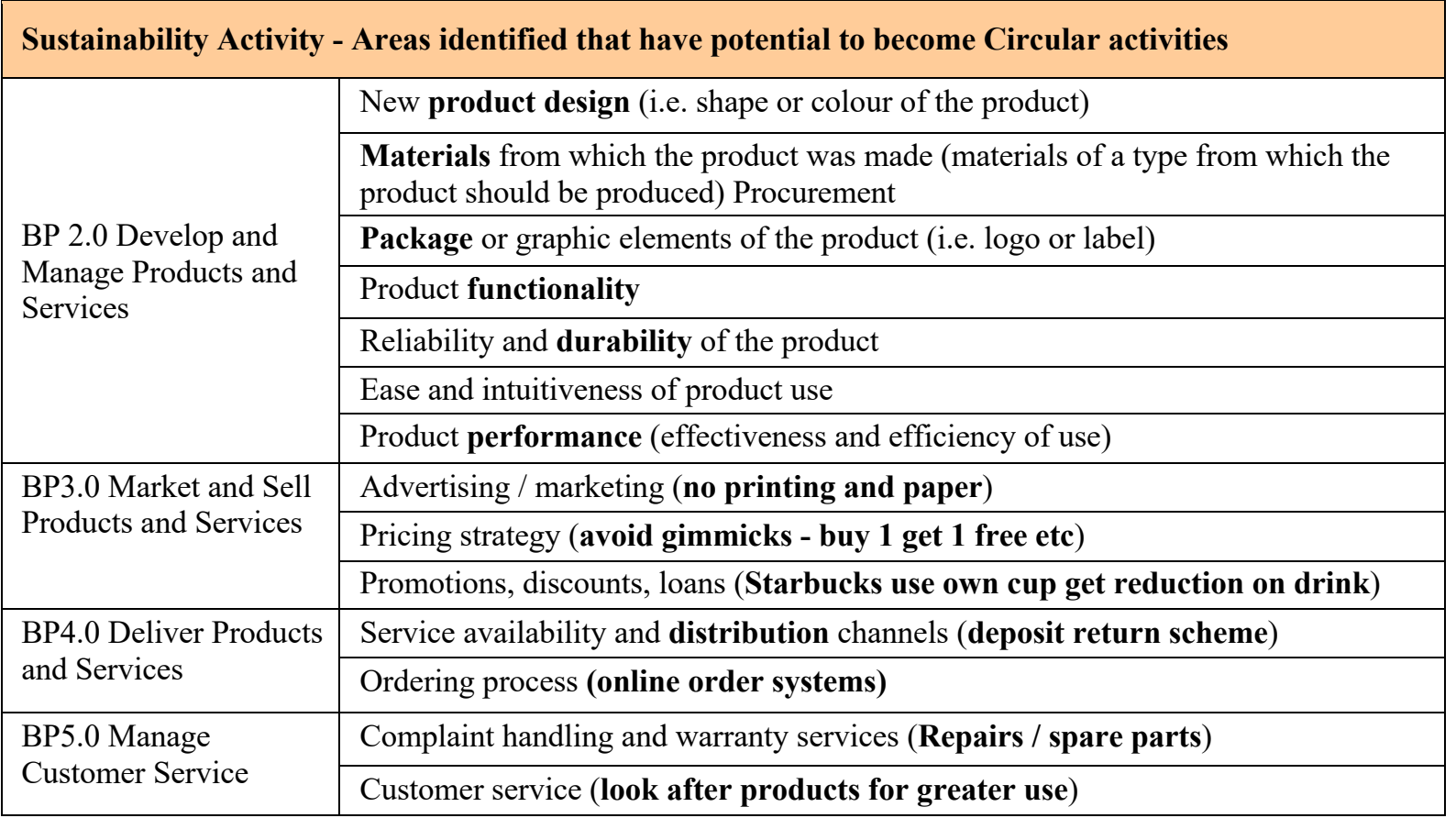

As the examples demonstrate, opportunities for prosumer-based CE activities can be found across all four business processes which could allow prosumers to contribute

\section{Conclusions}

This work contributes to extant research on prosumers' engagement in knowledge sharing by:

- addressing the kinds of knowledge that Poland and UK based prosumers share and are willing to share in the future, in response to emerging global challenges;

- proposing a novel conceptual model that explains the knowledge management systems that need to be in place to ensure it is a two-way communication process;

- proposing an approach that combines the concepts of prosumers' knowledge sharing and CE activities, incorporated in a conceptual framework;

- deriving evidence from the relevant literature of linkages between the concepts of being a prosumer and the $\mathrm{CE}$ as postulated in the conceptual framework.

The advance made by this study is that it proposes the first ever model attempting to explain how enterprises can capture knowledge from prosumers and translate that knowledge into actions that inform business strategy. 
The conceptual model of prosumer engagement is a notable element of this study as it illustrates;

- that prosumer's engagement is associated with four specific business process stages (BP2.0BP5.0); is influenced by the particular types of incentives offered; is mediated by the choice of specific ICT communication media available; and may be aligned with sustainability focused activities.

- how to combine the concepts of the prosumer and those of $\mathrm{CE}$ activities carried out by enterprises in a single conceptual model, illustrating that the two existing sets of separate concepts may be combined and be made compatible.

- that knowledge sharing is associated with prosumer engagement choices about the business based activities they engage in, the customer's motives, the communication tools they choose as part of the engagement and contemporary global challenges that are a growing concern for customer engagement with enterprises.

The conceptual model proposes a new combination of individual themes and illustrates a potential path of knowledge flow between customers and enterprises. The model is of use to enterprises in facilitating the redefinition of business strategies in relation to communication with customers, and in informing the implementation of systems that will encourage prosumer knowledge sharing and knowledge exchange. Poland and UK businesses, and indeed businesses in Western economies more widely, can use the approach to prosumer knowledge sharing proposed in this paper, to help restate their internal and external knowledge sharing strategies, and respond to prosumer expectations with awareness of the growing limitations imposed by a shrinking ecosystem that places specific challenges on enterprises. Whereas the specific findings of the study are limited to Poland and the UK, it can be concluded that the implications for businesses can be expanded to other Western countries or even globally.

\section{References}

Al-Alawi, A. I. (2005). The practice and challenges of knowledge management in financial sectors in Bahrain, Asian Journal of Information Systems, 4(1), 101-107.

APQC. (2016). Process classification framework. American Productivity and Quality Center. http://www.apqc.org/pcf

Baird, C. H., \& Parasnis, G. (2011). From social media to social customer relationship management. Strategy \& Leadership, 39(5), 30-37.

Barr, S., Gilg, A., \& Shaw, G. (2011). Citizens, consumers and sustainability: (Re)Framing environmental practice in an age of climate change. Global Environmental Change, 21, 1224-1233.

Belk, R. (2014). You are what you can access: Sharing and collaborative consumption online. Journal of Business Research, 67, 1595-1600.

Botsman, R., \& Rogers, R. (2010). What's mine is yours: The rise of collaborative consumption. Harper Collins. 
Bylok, F. (2013). Konsumpcja, konsument i społeczeństwo konsumpcyjne we współczesnym świecie [Consumption, the consumer and the consumer society in the modern world]. Katowice: Śląsk.

Cabrera, A., \& Cabrera, E. F. (2002). Knowledge sharing dilemmas. Organization Studies, 23(5), 687-710.

Chang, W., \& Taylor, S. (2016). The effectiveness of customer participation in new product development: A meta-analysis. Journal of Marketing, 80(1), 47-64. https://doi.org/10.1509/jm.14.0057

Chouikha, M. B. (2016). Organizational design for knowledge management. John Wiley \& Sons.

EMAF. (2012). Towards the Circular Economy. Report 1. Ellen MacArthur Foundation. https://www.ellenmacarthurfoundation.org/

EMAF. (2013). Towards the circular economy. Ellen MacArthur Foundation. https://www.ellenmacarthurfoundation.org/

EMAF. (2019). Completing the picture: How the circular economy tackles climate change. Ellen MacArthur Foundation. https://www.ellenmacarthurfoundation.org/publications

Galvao, G. D. A., De Nadae, J., Clemente, D. H., Chinen, G., \& De Carvalho, M. M. (2018). Circular economy: Overview of barriers. Procedia CIRP, 73, 79-85.

Geissdoerfer, M., Savaget, P., Bocken, N., \& Hultink, E. J. (2016). The circular economy - a new sustainability paradigm? Journal of Cleaner Production, 143, 757-768. https://doi.org/10.1016/j.jclepro.2016.12.048

Ghosh, A., \& Fedorowicz, J. (2008). The role of trust in supply chain governance. Business Process Management Journal, 14(4), 453-470.

Gnoni, M. G., Mossa, G., \& Mummo, G. (2017). Supporting circular economy through use-based business models: The washing machines case. Procedia CIRP, 64, 49-54.

Greenberg, J., \& Liebman, M. (1990). Incentives: The missing link in strategic performance. Journal of Business Strategy, 11(4), 8-11.

Groh, G., Brocco, M., \& Asikin, Y. A. (2010). Contribution awareness and fame in open innovation networks. In J. Hafkesbrink, H.-U. Hoppe \& J. Schlichter (Eds.), Competence Management for Open Innovation - Tools and IT-support to unlock the potential of Open Innovation, pp. 115-138. Josef Euler Verlag.

Hafkesbrink, J., \& Evers, J. (2010). Innovation 3.0: Embedding into community knowledge - The relevance of trust as enabling factor for collaborative organizational learning. XXI ISPIM Conference Bilbao, The Dynamics of Innovation.

Ho, L. A., \& Kuo, T. H. (2013). How system quality and incentive affect knowledge sharing. Industrial Management \& Data Systems, 113(7), 1048-1063. 
Huang, N., Burtch, G., Hong, Y., \& Polman, E. (2016). Effects of multiple psychological distances on construal and consumer evaluation: A field study of online reviews. Journal of Consumer Psychology, 26(4), 474-482. https://doi.org/10.1016/j.jcps.2016.03.001

Jabbour, C. J. C., Jabbour, A. B. L. S., Sarkis J., \& Filho M. G. (2019). Unlocking the circular economy through new business models based on large-scale data: An integrative framework and research agenda. Technological Forecasting and Social Change, 144(C), 546-552. https://doi.org/10.1016/j.techfore.2017.09.010

Janzik, L., \& Herstatt, C. (2008). Innovation communities: Motivation and incentives for community members to contribute. Proceedings of the 4th IEEE International Conference on Management of Innovation and Technology, 350-355.

Jordens, W. (2015). Building a collaborative advantage within a circular economy: interorganisational resources and capabilities of a circular value chain. Master's Thesis, Universiteit Utrecht. https://dspace.library.uu.nl

Kalmykova, Y., Sadagopan, M., \& Rosado, L. (2018). Circular economy - From review of theories and practices to development of implementation tools, Resources. Conservation \& Recycling, 135, 190-201. https://doi.org/10.1016/j.resconrec.2017.10.034

Korhonen, J., Honkasalo, A., \& Seppälä, J. (2018). Circular economy: The concept and its limitations. Ecological Economics, 143, 37-46. https://doi.org/10.1016/j.ecolecon.2017.06. $\underline{041}$

Kwon, I.-W. G., \& Suh, T. (2005). Trust, commitment and relationships in supply chain management: a path analysis. Supply Chain Management: An International Journal, 10(1), 26-33.

Lacy, P., \& Rutqvist, J. (2015). Waste to wealth: The circular economy advantage. Palgrave Macmillan.

Lan, J., Ma, Y., Zhu, D., Mangalagiu, D., \& Thornton, T. F. (2017). Enabling value co-creation in the sharing economy: The case of Mobike. Sustainability, 9, 1504. https://doi.org/10.3390/su9091504

Lauman, F., \& Tambo, T. (2018). Enterprise architecture for a facilitated transformation from a linear to a circular economy. Sustainability, 10(11), 3882. https://doi.org/10.3390/su1011 $\underline{3882}$

Lee, S. C., \& Kelkar, R. S. (2013). ICT and knowledge management: Perspectives from SECI model, The Electronic Library, 31(2), 226-243. https://doi.org/10.1108/02640471311 $\underline{312401}$

Lieder, M., \& Rashid A. (2016): Towards circular economy implementation: A comprehensive review in context of manufacturing industry. Journal of Cleaner Production, 115, 36-51.

Michelini, G., Moraes, R. N., Cunha, R. N., Costa, J. M. H., \& Ometto A. R. (2017). From linear to circular economy: PSS conducting the transition. Procedia CIRP, 64, 2-6. 
Moric, I., Jovanovic, J. S., Dokovic, R., Pekovic, S., \& Perovic, D. (2020). The effect of phases of the adoption of the circular economy on firm performance: Evidence from 28 EU countries. Sustainability, 12, 2557. https://doi.org/10.3390/su12062557

Mullins, R., Eisenbardt, M., Dettmer, S., \& Ziemba, E. (2019). Value added knowledge by prosumers in Poland and the UK specifically for service process stages. Online Journal of $\begin{array}{llll}\text { Applied } \quad \text { Knowledge } & \text { Management, } & \text { 7(1), }\end{array}$ https://doi.org/10.36965/OJAKM.2019.7(1)102-126

Nonaka, I. (1994). Dynamic theory of organizational knowledge creation. Organization Science, 5(1), 14-37. https://doi.org/10.1287/orsc.5.1.14

Nonaka, I., \& Takeuchi, H. (1995). The knowledge creating company: How Japanese companies create the dynamics of innovation. Oxford University Press.

Orzan, G., Cruceru, A., Bălăceanu, C., \& Chivu, R.-G. (2018). Consumers’ behavior concerning sustainable packaging: An exploratory study on Romanian consumers. Sustainability, 10(6), 1787. https://doi.org/10.3390/su10061787

Pagoropoulos, A., Pigosso D. A., \& McAloone T. C. (2017). The emergent role of digital technologies in the circular economy: A review. Procedia CIRP, 64, 19-24.

Piller, F. (2008). Interactive value creation with users and customers. http://www.masscustomization.de/download/piller 2008-pribilla.pdf

Ramus, C. A., \& Montiel, E. (2005). When are corporate environmental policies a form of Greenwashing. Business \& Society, 44, 377-414.

Reim, W., Lenka, S., Frishammar, J., \& Parida V. (2017). Implementing sustainable productservice systems utilizing business model activities. Procedia CIRP, 64, 61-66.

Ritzer, G., \& Jurgenson, N. (2010). Production, consumption, prosumption: The nature of capitalism in the age of the digital 'prosumer'. Journal of Consumer Culture, 10(1), 13-36.

Ritzen, S., \& Sandström, G. (2017): Barriers to the circular economy - integration of perspectives and domains. Procedia CIRP 64, 7-12.

Rizos, V., Behrens, A., Kafyeke, T., Hirschnitz-Garbers, M., \& Ioannou A. (2015). The circular economy: Barriers and opportunities for SMEs. CEPS working document, no. 412.

Romero, D., \& Rossi, M. (2017). Towards circular lean product-service systems. Procedia CIRP, 64, 13-18.

Seran (Potra), S., \& Izvercian, M. (2014). Prosumer engagement in innovation strategies: The prosumer creativity and focus model. Management Decision, 52(10), 1968-1980. https://doi.org/10.1108/md-06-2013-0347

Stahel, W. (2016). Circular economy. Nature, 531, 435-438.

Swan, J., Newell, S., \& Robertson, M. (2000). Limits of IT-driven knowledge management for interactive innovation processes: Towards a community-based approach. Proceedings of the 33rd Hawaii International Conference on System Sciences. 
Tapscott, D., \& Williams, A. D. (2006). Wikinomics: How mass collaboration changes everything. Penguin Group.

Tukker, A. (2015). Product services for a resource-efficient and circular economy - A review. Journal of Cleaner Production, 97, 76-91. https://doi.org/10.1016/j.jclepro.2013.11.049

Tura, N., Hanski, J., Ahola, T., Ståhl, M., Piiparinen, S., \& Valkokari, P. (2019). Unlocking circular business: A framework of barriers and drivers. Journal of Cleaner Production, 212, 90-98. https://doi.org/10.1016/j.jclepro.2018.11.202

Upadhyay, A., Akter, S., Adams, L., Kumar, V., \& Varma, N. (2018). Investigating "circular business models" in the manufacturing and service sectors. Journal of Manufacturing, Technology Management, 30, 590-606. https://doi.org/10.1108/JMTM-02-2018-0063

Vivek, S. D., Beatty, S. E., \& Morgan, R. M. (2012). Customer engagement: Exploring customer relationships beyond purchase. Journal of Marketing Theory and Practice, 20(2), 122-146. https://doi.org/10.2753/MTP1069-6679200201

Vuori, V., \& Okkonen, J. (2012). Knowledge sharing motivational factors of using an intraorganizational social media platform. Journal of Knowledge Management, 16(4), 592603.

World Economic Forum (2014). Towards the circular economy: Accelerating the scale-up across global supply chains. World Economic Forum: Ellen MacArthur Foundation and McKinsey \& Company.

Xie, C., Bagozzi, R. P., \& Troye, S. V. (2008). Trying to prosume: Toward a theory of consumers as co-creators of value. Journal of the Academy of Marketing Science, 36, 109-122.

Ziemba, E., \& Eisenbardt, M. (2015). Prosumers' participation in business processes. Online Journal of Applied Knowledge Management, 3(1), 114-127.

Ziemba, E., \& Mullins, R. (2016). Identifying more about customers: The phenomenon of the switch to the knowledge exchange. Online Journal of Applied Knowledge Management, 4(1), 165-179. https://doi.org/10.36965/OJAKM.2016.4(1)165-179

Ziemba, E., \& Eisenbardt, M. (2016). Incentives encouraging prosumers to knowledge sharing framework based on Polish study. Online Journal of Applied Knowledge Management, 4(2),146-166. https://doi.org/10.36965/OJAKM.2016.4(2)146-166

Ziemba, E., Eisenbardt, M., \& Mullins, R. (2016). Information and communication technologies for supporting prosumers knowledge sharing - evidence from Poland and United Kingdom. Proceedings of the 2016 Federated Conference on Computer Science and Information Systems FedCSIS, 1, 1273-1282. https://doi.org/10.15439/2016F285

Ziemba, E., Eisenbardt, M., Mullins, R., \& Grabara, D. (2017). Investigating incentives that encouraged and can encourage Polish and UK-based prosumers to engage in knowledge sharing. Online Journal of Applied Knowledge Management, 5(1), 72-100. https://doi.org/10.36965/OJAKM.2017.5(1)72-100 
Ziemba, E., Eisenbardt, M., Mullins, R., \& Grabara, D. (2018). Prosumers knowledge sharing to develop and manage products. Online Journal of Applied Knowledge Management, 6(2), 72-91. https://doi.org/10.36965/OJAKM.2018.6(2)72-91

Ziemba, E., Eisenbardt, M., Mullins, R., \& Dettmer, S. (2019). Prosumers' engagement in business process innovation - The case of Poland and the UK. Interdisciplinary Journal of Information, Knowledge, and Management, 14, 119-143. https://doi.org/10.28945/4320

\section{Authors Biographies}

Roisin Mullins completed her Ph.D. in the development and evaluation of elearning systems, learning communities and business training systems. She is an Associate Professor at the University of Wales Trinity Saint David in the UK. She has published over 50 peer-reviewed pieces including conference papers, book chapters and international journal papers. Roisin Mullins serves on the editorial boards of several international conferences. Her research has emphasized practical solutions to technology problems or novel applications of

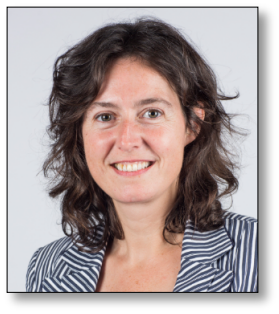
technology, so that in addition to answering a question, the research outcomes have informed policy and practice guidelines at the European level and decision-making processes in the SMEs of EU member countries. She is a Fellow \& Distinguished Scholar of the Institute and received the Lifetime Academic Achievement Award from the International Institute for Applied Knowledge Management in 2019, and several Best Papers awards received at international conferences.

Sandra Dettmer completed her Ph.D. in Labour Economics where she investigated regional disparities between earnings, unemployment and publicprivate sector pay across the UK. She is currently employed as Senior Lecturer at the School of Business and Society at University of South Wales. Her other research interests focus on returns to education and pedagogy. Prior to her academic career, she worked in the private sector and gained insights into business operations during her consultancy work.

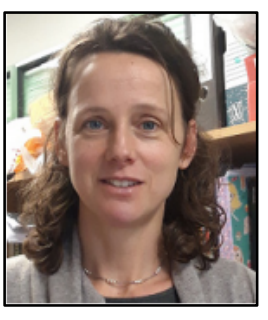

Monika Eisenbardt completed her Ph.D. with a major focus on management information systems as well as changes and challenges involving modern consumers. She is an Assistant Professor at the University of Economics in Katowice, Poland. Her current research focuses on innovations, ICT, consumers' knowledge and their willingness to knowledge sharing. She has published over 30 peer-reviewed pieces including conference papers, book chapters and international journal papers. She is a Fellow \& Distinguished Scholar of the Institute for Applied Knowledge Management and several The Best Papers

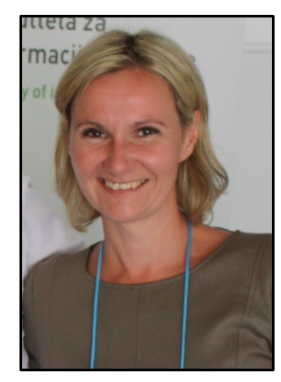
awards received at international conferences. Monika serves as the Editorial Assistant for Journal of Economics and Management - the official international journal of University of Economics in Katowice. 
Ewa Ziemba completed her Ph.D. and Post Ph.D. in Management, with a major focus on management information systems. She is a Full Professor at the University of Economics, Katowice, Poland. Her current research focuses on information systems and technologies for business and public administration transformation. She has published over 200 peer-reviewed papers, 20 books and has played an instrumental role in prestigious Polish and international research projects. Ewa Ziemba serves on the editorial boards of several international journals. Ewa Ziemba has received numerous awards for research and teaching,

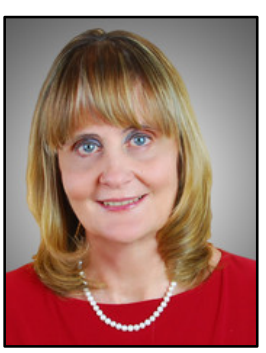
including Prize of Polish Minister of Science and Higher Education for excellent research achievement, Excellent Awards of the President of the University of Economics in Katowice, Silver Cross of Merit from the President of Poland, Medal of the National Education Commission from the Ministry of National Education in Poland, The Award of Fellow \& Distinguished Scholar and The Excellence in Research \& Scholarship Award from the International Institute for Applied Knowledge Management, and several Best Papers awards. 